\title{
Fostering Diversity Values Through Learning The History of The National Movement in Senior High Schools
}

\author{
Muslim $^{1 *}$, Warto $^{2}$, Djono $^{3}$ \\ ${ }^{1,2,3}$ Universitas Sebelas Maret Surakarta, Indonesia \\ *e-mail: muslim_161194@yahoo.com
}

\begin{abstract}
This study aims to find out how to foster the value of diversity through learning the history of the national movement in Senior High Schools. This study uses a qualitative method, with a single case study strategy. This research was conducted at the National Senior High School. The data validity was used triangulation. Data were collected through interviews, a document study, and observation. The data analysis technique used the interactive model of Miles and Huberman analysis. The results of the study: 1) Planning, the history teacher has prepared and compiled a lesson plan which contains the values of diversity. 2) Implementation, history teachers teach material about national movement figures, use discussion methods, train students to respect friends who are different from them such as differences in religion, ethnicity, race, ethnicity, social system, and culture. 3) Evaluation, history teachers have used the principle of overall evaluation and continuity and have been implemented properly by history teachers. 4) Barriers because currently learning is carried out online, so teachers cannot see what students are doing as it is when learning is done in class. In the end, this study showed that after the obstacles were overcome, the students' diversity values increased.
\end{abstract}

Keywords:

Diversity Values; Senior High School; History of The National Movement

\begin{abstract}
ABSTRAK
Kajian ini bertujuan untuk mengetahui bagaimana menumbuhkan nilai kebhinekaan melalui pembelajaran sejarah pergerakan nasional di Sekolah Menengah Atas. Kajian ini mengunakan metode kualitatif, dengan strategi studi kasus tunggal. Penelitian ini dilaksanakan di Sekolah Menengah Atas Kebangsaan. Validitas data menggunakan triangulasi. Data dikumpulkan melalui wawancara, studi dokumen, dan observasi. Teknik analisis data mengunakan model analisis interaktif Miles dan Huberman. Hasil kajian: 1) Perencanaan, guru sejarah telah menyiapkan dan menyusun RPP yang didalamnya tertuang nilai-nilai kebhinekaan. 2) Pelaksanaan, guru sejarah mengajarkan materi tentang tokoh pergerakan
\end{abstract}


nasional, mengunakan metode diskusi, melatih siswa untuk menghargai teman yang berbeda dengannya seperti perbedaan agama, suku, ras, etnis, sistem sosial, maupun budayanya. 3) Evaluasi, guru sejarah telah mengunakan prinsip evaluasi keseluruhan dan kesinambungan serta telah dilaksanakan dengan baik oleh guru sejarah. 4) Hambatan, karena saat ini pembelajaran dilakukan secara daring (online), sehingga guru tidak dapat melihat apa saja yang dilakukan oleh siswa sebagaimana halnya ketika pembelajaran dilakukan dikelas. Pada akhirnya kajian ini setelah hambatan diatasi, maka nilai-nilai kebhinekaan siswa meningkat.

\section{Kata Kunci:}

Nilai Kebhinekaan; Sekolah Menengah Atas; Sejarah Pergerakan Nasional

\section{Introduction}

The Indonesian nation is a nation that is rich in cultural heritage that is stored in regional culture throughout the archipelago which spreads from Sabang to Merauke (Pambud et al, 2020). The current development harms the general public where technological advances create a world without borders and it is easy to find the information needed, but this convenience is not matched by clear filters and causes abuse. Source of information among adolescents, resulting in juvenile delinquency. The loss of indigenous personalities or what is called a symptom of cultural erosion is also one of the factors of failure in fostering youth character. Indonesia has a high and noble cultural heritage whose teachings are no less important than Western teachings (Pambud et al, 2020). Diversity is part of the life of Indonesian society. The diversity in question is the diversity of Indonesian society which includes ethnicity, religion, race, class, language, culture, customs, and so on (Pi'i, 2017).

Diversity does not occur suddenly but through a long historical process (Indah \& Widiadi, 2016). Long before Western society promoted the discourse of multiculturalism, Indonesians had lived with a very rich diversity which included ethnicity, language, customs, religion, and so on (Indah \& Widiadi, 2016). This diversity is a gift to the people of Indonesia. However, if it cannot be addressed properly, diversity will become a disaster. After the 1998 reformation, there were various conflicts due to differences in ethnicity or religion in Indonesia, such as the Sampang, Poso conflicts, and the Shia conflict in Madura. These incidents need not occur if we are to learn from the history of the Indonesian nation. Indonesia's founding fathers consisted of various ethnic, religious, and even ideological backgrounds, but they managed to get rid of their personal or group egoism for the sake of the nation and state. It is not surprising that they included the motto of Bhineka Tunggal Ika in the national symbol (Indah \& Widiadi, 2016).

Learning the history of national movements is very important to be taught to students to make students aware of the process of change and development of society in the dimension of time to build students' historical perspective and awareness to find, understand and explain national identity in the past, present, and future is in the midst of world change, and as a reference to build national unity, it 
is felt that it is important to foster the values of diversity from an early age. Indonesia is a nation that has a unique character, consisting of various religions, races, tribes, and languages which are divided into several islands. This phenomenon is often referred to as plurality (Muawanah, 2018).

Indonesia is a country with various religions and cultures. Indonesia is considered a country that upholds the values of tolerance between religions. Indonesia is not only known as a multicultural country that has various ethnicities and cultures, but is also called a multi-religious country in which there are various religions, not only Islam, Protestant Christianity, Catholic Christianity, and Buddhism, but also Hinduism (Muhaemin \& Sanusi, 2019). Our distinctive motto "Bhineka Tunggal Ika" that we have has united the Indonesian people in one unified whole with one bond called the Unitary State of the Republic of Indonesia (NKRI), united in diversity, and harmony in differences, therefore it is a keyword that cannot be contested (Muhaemin \& Sanusi, 2019). The Indonesian state is not synonymous with certain religions because the state protects all religions that its people want to embrace as long as they do not deviate. The state also does not remove religion from state affairs. The state is responsible for the existence of religion, religious life, and religious harmony (Pujiono et al, 2019).

The relationship between religion and the state in Indonesia can be seen from religious institutions, laws, and regulations relating to religion or religious life, and other policies related to religious life (Pujiono et al, 2019). The Constitution has guaranteed freedom of religion as stipulated in Article 28 E paragraph (1), Article 29 paragraph (2) of the 1945 Constitution of the Republic of Indonesia. Even though there is a guarantee of religious freedom in the constitution, it does not mean that such freedom is unlimited. Article 28 I of the 1945 Constitution of the Republic of Indonesia states that everyone is obliged to respect the human rights of others in exercising their rights and freedom of religion with the limitation that they do not conflict with laws, morals, religious values, security, order, and morals (Pujiono et al, 2019). Religious and religious intolerance in Indonesia in the framing Kompas is also defined as a problem of education, whether those related to the education system are considered only to teach knowledge and recognition, have not yet reached real appreciation and experience in the field, or those related to awareness of diversity (Muhaemin \& Sanusi, 2019).

Table 1. Sample of Compass Intolerance News for April 2017

\begin{tabular}{ccc}
\hline Number & APRIL & \\
\hline 1 & The Scholars Want Peace & April 5, 2017 \\
2 & Intolerance due to lack of understanding of religion & April 6, 2017 \\
3 & Sticking out a commitment to realizing digital literacy & April 6, 2017 \\
4 & Intelligent Clerics Are Needed More & April 8, 2017 \\
5 & Minister of Religion: Prioritize Moderate Understanding & April 13, 2017 \\
6 & Indonesia-Islam Cannot be Contested & 19 April 2017 \\
7 & Young Generation Invited to Strengthen Diversity & 22 April 2017 \\
8 & Inter-Religious Harmony Becomes the Capital of the Nation & April 25, 2017 \\
\hline
\end{tabular}

Source: (Muhaemin \& Sanusi, 2019: 22). 
Table 2. Sample of Compass Intolerance News for May 2017

\begin{tabular}{ccc}
\hline Number & \multicolumn{2}{c}{ MAY } \\
\hline 1 & Religious Harmony Laboratory & 2 May 2017 \\
2 & The Spirit of Pluralism Needs to Be Strengthened from an & 22 May 2017 \\
& Early Age & \\
3 & Megawati: Diversity as a National Character & 26 May 2017 \\
4 & Government Launches Pancasila Week & 27 May 2017 \\
5 & Government Asked One Language in Attitude & 27 May 2017 \\
6 & Support for Anti-radicalism Widespread & 29 May 2017 \\
\hline
\end{tabular}

Source: (Muhaemin \& Sanusi, 2019: 22).

Intolerance is still a big concern in this country. The intolerance that occurs in Indonesia generally occurs due to differences in religion and belief. Many cases of intolerance occur in the name of religion. For example, the rejection of Shia by the Islamic Community Forum in Central Java and the refusal to build a mosque in Manado in September 2016 (Muslim et al, 2020). Indonesian society is a society that has a very complex diversity, a society with various diversity is known as a multicultural society. The multiculturalism that is formed in Indonesia is the result of diverse and extensive socio-cultural and geographical conditions (Nugroho \& Putri, 2016).

According to Appadurai (1993), the global cultural flow can be understood through the relationship between the five components that characterize global culture. The five components, namely (1) ethnoscapes, (2) technoscapes, (3) mediascapes, (4) finanscapes, and (5) ideoscapes. The five components include Ethnoscapes, which is the movement of people or people from one country to another. Examples of tourists, immigrants, refugees, labor are the characteristics of global culture. Technoscapes or often called the flow of technology that flows so fast to all countries. Mediascapes is the dissemination of information through the media to all parts of the world. F finances is a financial aspect that seems a bit difficult to predict in the era of globalization. Ideoscapes refer to components that are related to political issues, such as democracy, sovereignty, welfare, rights, and freedoms.

Globalization is very threatening to youth because the psychological condition of youth is still unstable so that they are easily influenced from the outside. Today's youth are very susceptible to the impact of westernization so that they can instantly change the values that have been held so far. Youth are less aware of these threats and do not consider the importance of the values of tolerance and patriotism. Recently, student brawls, clashes between residents, pornography, thuggery, prostitution, promiscuity when far from the attention of their parents, dress casually without thinking about customs, and worse, no longer respect their parents (Muslim et al, 2020).

Learning values that are starting to fade at this time have had a considerable impact on student behavior because students prefer to fight, bullying and have reduced awareness in students of the values of heroism, values of tolerance, and patriotism (Rohmat, 2004). The values above are values that were born from the long process of the history of the Indonesian people. These character values are very important and are still relevant to be internalized by students. As long as this country still adopts the Pancasila ideology, the character values that exist in Pancasila must still be passed on to 
the younger generation. Subjects in school, one of the subjects is history. By the educational objectives contained in the 1945 Constitution and the 2003 Law on SIKDIKNAS, history learning has a very important role in shaping a young generation with character and personality according to the identity of the Indonesian nation (Muslim et al, 2020).

Value is good, valuable, based on standards of thought (right or wrong), aesthetics (good or bad), ethics (fair or unfair), religion (sin or not), as well as guidelines in human life (Muslim et al, 2020). Value is the essence attached to something beneficial to human life. Values are abstract, ideal, not objects, and not facts/concrete. Values serve as guidelines and considerations in determining behavior in human life regarding things that are good or bad (Thoha, 1996). The values of diversity are values (something that is essential) that are used as guidelines for determining good or bad behavior in the life of a society that is rich in diversity. These values become a reference, foundation, and glue for the preservation of the diversity of Indonesian society (Pi'i, 2017). Diversity values need to be instilled and cultivated in schools. The middle school has a very big role in shaping the student's personality. Middle school has slowly become a place to replace what families do. As students intensively enter social spaces through spaces in middle schools, students can socialize with other students and their teachers in secondary schools (Muslim et al, 2020).

Multicultural education in it, everyone is placed in an equal and equal position, respects differences, recognizes and accepts prevailing values, strengthens peace, solidarity, and the ability to resolve conflicts peacefully, so that the cultivation of diversity values can form students who have quality in developing tolerance, patience and maintaining the habit of sharing (Pi'i, 2017). The values of diversity that need to be instilled in students according to Amuk (2016) include (1) the value of tolerance is an attitude to recognize and respect human rights in social life, (2) the value of equality is an attitude that emphasizes equality and equality towards culture other tribes, (3) the value of democracy is an attitude that recognizes that everyone has the same rights and obligations, and recognizes diversity as a natural thing, and (4) justice is an act that gives equal rights to people who have the same status (Pi'i, 2017).

Rowse (1963) says that history lessons are subjects that have higher educational value. Collingwood (1973) asserts that historical values provide knowledge to humans and what they have done. In the context of forming a national identity, history lessons have a fundamental function (Setianto, 2019). When the role of national history learning which can encourage the understanding of nationalism and national integration occurs, we are aware that since the "discovery of national identity" on October 28, 1928, symbolically this identity has been approved in the Youth Pledge as a new community (Supardan, 2009). This pledge was not the result of mere contemplative reflection but was preceded by a search, debate, and tense conflict (Supardan, 2009). Anderson (1983) mentions the role of national history as a national identity and the development of national consciousness. Furthermore, Anderson also sees the importance of national identity as the most powerful and longlasting influence in collective cultural identity. Then according to Vanderburg (1985), he adds that apart from that through learning national history, he also seeks to form behavioral models that foster 
cultural nationalism to create patterns of relationships that transcend the temporal and spatial environment and other dimensions.

Several previous studies are relevant to this study, First Muslim, Warto, and Djono (2020). The results show that: (1) Instilling the values of tolerance and patriotism in students, namely through learning preparation, implementation of learning (using the discussion method, because in the discussion it is easy to instill the values of tolerance and patriotism in students), and evaluation (2) The difficulty faced by history teachers is that they have little learning time, and currently online learning makes it difficult for teachers to socialize with students. (3) The efforts made by history teachers in overcoming these difficulties were to make themselves role models and motivators for their students. Second, Sahal, Musadad, and Akhyar (2018). Discussing multicultural education is education that prioritizes basic skills for world citizens, important for all students, through all aspects of the education system such as knowledge, building attitudes and skills that allow students to work for social justice. Third, Utami \& Widiadi (2016). The results of the research show that Bhineka Tunggal Ika is represented in various themes such as assimilation, acculturation, syncretism, difference, diversity, plurality, plurality, multiculturalism, differentiation/ discrimination, and unity and unity. Bhineka Tunggal Ika needs to be understood as a result as well as an ongoing process.

The difference between previous research and the study carried out in this study is that this study examines and describes the growing values of diversity through learning the history of the national movement, the material of which is that the teacher teaches and introduces historical figures of the national movement who had a major influence in fighting for Indonesian independence, such as Sukarno, Mohammad Hatta, Ki Hajar Dewantara, RA Kartini, Fatmawati, Nyi Ageng Serang, Siti Manggapoh, Soedirman, Sutomo, Sutan Sjahrir, Muhammad Yamin, Dr. Cipto Mangunkusumo, Douwes Dekker, K.H Agus Salim, Dr. Wahidin Sudirohusodo, KH. Ahmad Dahlan, KH. Hasyim Asy'ari, H.O.S. Tjokroaminoto, H. Samanhudi. From some of the relevant research above, there are efforts to instill the values of tolerance and patriotism of students in history learning, as well as this study which aims to describe efforts to foster diversity values through learning historical figures of the national movement, so that diversity values can be found. Lived, understood, and manifested in the daily life of students. Based on the description above, a question arises in this study on how to cultivate the values of diversity through learning the history of the national movement.

\section{Methods}

This study uses a qualitative method that aims to obtain a clearer and more in-depth description of the ongoing situation which describes the actual situation, which is useful for supporting data presentation which emphasizes more on the process and its meaning. This study emphasizes more on efforts to foster diversity values through learning the history of the national movement at National Senior High School, Yogyakarta. This study uses a single case study strategy. According to Yin (2003), a case study is an empirical inquiry that investigates phenomena in real life if the boundary between phenomena and context is not visible and multiple sources can be exploited. According to Yin (2003), a case study is called embedded because it is tied to its predetermined unit of analysis. 
Primary and secondary data types. Primary data includes the results of interviews with the principal of National Senior High School, history teachers, deputy principal of the curriculum section, deputy principal of public relations, which have been carried out in the field and then the results of this interview are recorded using a cellphone then recorded through written notes, while the secondary data includes books, Reputable journals that are relevant to this study, RPP (Learning Implementation Plan, Student Worksheet) in the form of individual papers and mind mapping group assignments. Three data sources for this study are used or utilized, namely: informants, locations, and activities, as well as documents.

This study uses purposive sampling, which is the basis for the use of purposive sampling because, in sampling, it can select informants selectively by considering the capabilities of the informants with certain considerations. The data collected was in the form of written and spoken words from someone whose behavior was observed, so that the data collection techniques used in the data collection process were through in-depth interviews, a document study, and observation. The data validity of this study uses triangulation to obtain valid data. The triangulation used in this study is source triangulation (data) and method triangulation. The data analysis technique used the interactive model of Miles and Huberman's analysis.

\section{Results and Discussion}

\subsection{Learning Planning}

Planning for the history of the national movement to foster diversity values has been carried out by the history teacher concerned. Planning is a very important initial process, according to the statement of the history teacher at National Senior High School who said:

"The history teacher has inserted and included the values of diversity in their planning. When compiling a lesson plan, the lesson plan (RPP) includes 1) the title of the lesson, 2) the name of the teacher, 3) the class or the semester, 4) the subject matter, 5) the amount of time, 6) the IQ 7) KD 8) the learning objectives, 9) Subject matter, 10) Learning methods, 11) Learning media, 12) Learning sources, 13) Learning activities, 14) Types of assessment" (interview 3 July 2020).

Regarding the history lesson planning for the national history teacher movement, he said:

"The planning stage for the history of the national movement in National Senior High School has been planned very well by the history teacher. This can be proven that there are learning tools that have been prepared and adapted to the 2013 curriculum" (interview 3 July 2020).

Furthermore, the history teacher said: 
"In the learning device, it has been equipped with several things starting from the short term and long term, learning preparation which includes all learning tools, for example, the education calendar, annual program, a semester program, KKM, syllabus, and lesson plans (lesson plan implementation" (interview 3 July 2020).

When compiling the lesson plans for learning the history of the national movement according to the provisions of the 2013 curriculum, which in history teacher learning uses the discussion method, with the Discovery Learning model, the teacher is only a facilitator in learning, because in learning students are encouraged to be more active, than the teacher, in teaching the history of the national movement, especially teachers discussing the material of Indonesian national movement figures such as Sukarno, Mohammad Hatta, Ki Hajar Dewantara, RA Kartini, Fatmawati, Nyi Ageng Serang, Siti Manggapoh, Soedirman, Sutomo, Sutan Sjahrir, Muhammad Yamin, Dr. Cipto Mangunkusumo, Douwes Dekker, K.H Agus Salim, Dr. Wahidin Sudirohusodo, KH. Ahmad Dahlan, KH. Hasyim Asy'ari, H.O.S. Tjokroaminoto, H. Samanhudi. Through group discussions in which the teacher divides students into several groups then 1 national movement organization material is discussed by two groups, the teacher instructs students to make individual papers and the task of making Mind Mapping in groups then Student work results are presented and friends who do not present listen to the discussion and each group that does not appear is obliged to ask questions to the group that appears, and for groups that do not presentations are given five questions, while the group that appears is ordered to summarize the results of the discussion, so that Students who have not appeared can also get ready to find answers to the questions given by the teacher and give questions to the presentation group, and after the discussion is complete students are given a post test with five questions that must be answered by students, discussion and question and answer is now being carried out by through social media WhatsApp, Google School, and Google Classroom, because at this time the learning process is carried out online, then for the material and power points sent through Google School and Google Classroom, the teacher checks the student's work that has been completed (interview 3 July 2020).

\subsection{Implementation of Learning}

Education is an effort to prepare students for the increasingly rapid changes in their environment. Changes that occur in the community include the values that have been agreed upon by the community. Meanwhile, all values that have been approved by the community are called culture. Culture is said to be a concept that has high complexity (Zais, 1976). After the teacher inserts the values of diversity in the learning planning, the next stage of the learning process has its character to foster the values of diversity through the teaching of the history of the national movement.

"Learning the history of the national movement in the learning process uses the discussion method because in discussions it is easy to foster the values of diversity to 
students, for example, students are trained to speak confidently in front of a crowd, students are trained how to respect the opinions of other friends, students practice how to communicate. Which is good by expressing their opinions and responding to the opinions of others, and how to work together in completing their assignments with friends" (interview 3 July 2020).

The implementation of learning the history of the national movement at National Senior High School has been planned in the learning tools. This is what Sudjana (2010) said. Sudjana said that the implementation of learning is a process that arranges in such a form according to certain steps so that implementation can achieve the desired thing. The implementation of internalized historical learning together with the values of diversity consists of three stages of activities, namely preliminary activities, core activities, and closing activities. The learning implementation is carried out by the teacher using learning methods, media, and resources. Learning the history of the national movement is a suitable means of fostering the values of diversity in students, especially since National Senior High School is a school that was the venue for Budi Utomo's first congress in 1908, which became a symbol of national awakening (interview 3 July 2020).

The national movement is the first monument to the existence of a concept of the Dutch East Indies society to carry out resistance to Dutch colonialism through the appreciation or internalization of nationalism (Reni \& Sudrajat, 2017). The history of the period of the national movement can be said to be a form of economic activity, social activity, political activity, and cultural activity that describes the goals and motivations, and adaptations of the activities of organizations during the national movement (Suhartono, 1994).

The history of the national movement in Indonesia is a history that includes the flow contained in history that leads to the direction that shapes the nation and state as well as of nationalism in Indonesia. Knowledge of the history of the national movement means the understanding or mastery of important events that took place from 1908-1945, which began with the establishment of a national movement organization called the Budi Utomo organization until the formation of the Indonesian nation. The event described is a form of a series of efforts to escape from foreign invaders, to make the country independent, sovereign, just, and prosperous. The history of the national movement is a historical phenomenon or a result of the development of interacting economic, social, political, cultural, and religious factors. The history of the national movement can be said to be a form of economic movement, social movement, political movement, and cultural movement that explains the motivation and purpose, and orientation of the activities of the national movement organization (Trisnowaty, 2009).

According to Driyarkara, there are five values: vital values, beauty values, truth values, moral values, and religion (Driyarkara, 1980). Values still need to be activated in real life (Sudarsih, 2019). Meanwhile, according to Ki Hadjar Dewantara, culture is everything related to culture. Culture comes 
from the word "budi" as a mature soul, culture or culture is the fruit of the human mind (Ki Hadjar Dewantara, 1967). Santayana revealed that value is a form of view in science, not less than the truth in life. This principle says that value is something very important and needs to exist in life as a reference for action (Hazlitt, 2003). Bhinneka Tunggal Ika contains pluralistic and multiculturalistic concepts in life that are bound in unity. Pluralism is not pluralism, a notion that leaves diversity as it is. Letting each entity show differences regardless of the common denominator in that diversity. The concept of pluralism does not need a concept that substitutes diversity, as is the case with the multiculturalism of society which adheres to the ideas of pluralism and multiculturalism, like a pile of building materials that are allowed to pile up individually, so that they will not form a building called a house (Rambe, 2017).

Learning the history of the national movement uses the discussion method because in discussions it is easy to foster diverse values in students (interview 3 July 2020). Regarding the learning of the history of this national movement, the history teacher said:

"For example, students are trained to confidently speak in front of a crowd, students are trained how to respect the opinions of other friends, students practice how to communicate well by expressing their opinions and responding to the opinions of other students, but because now learning is done online, The teacher instructs students to make individual papers and group mind mapping, then this assignment will later be uploaded to the Google Classroom, the learning is carried out online (online) but the students' cooperation in completing their assignments is still well established' (interview 3 July 2020).

The discussion method according to Usman (2008) in Ilyasin, Amin, and Atmaja, (2019) states that group discussion is an orderly process that involves a group of people in informal face-to-face interactions with various experiences or information, concluding or a solution to the problem. According to Dewa Ketut Sukardi (2008) in Ilyasin, Amin, and Atmaja, (2019) group discussion is a meeting of two or more people, which is shown to exchange experiences and opinions, and usually results in a joint decision.

Regarding the implementation of history learning of the national history teacher movement, the statement said:

The learning material for the history of the national movement can foster diversity values in students, especially National Senior High School benefited from its history where this school was once the venue for Budi Utomo's first congress in 1908, and the students came from various (heterogeneous) regions. Whether ethnicity, social system, religion, and culture, where students embrace Islam, Christianity and Hinduism and history teachers can choose what methods, media, and strategies to use depending on how history teachers use them, especially online because Currently, the learning process is through the social media WhatsApp, Google Classroom because all themes 
can be adjusted according to the learning methods and media used. For example, this national movement figure material is more suitable for using the group discussion method, individual paper assignments because with this group discussion students can be trained to be more confident when speaking and expressing their opinions, and students can work together with their groupmates in solving a problem. Or problems and there can be a sense of diversity between students because students in this discussion are trained how to respect the opinions of other friends and listen to their friends during paper presentations, as well as their discipline and responsibility in completing individual and group assignments (interview 3 July 2020).

The implementation of learning the history of the national movement to foster the values of diversity in students is quite good and effective where the implementation process is the first teacher asking questions to students about the material being studied by students, the two teachers form students in several groups because the learning method used is the method of learning. Discussion, the three individual papers that do not present are required to give questions to the papers that appear or those that are presentations, and after the discussion is over the teacher gives five questions to students who did not present and after the discussion of individual and group papers are completed. They are always given a post-test so that after each discussion it is good groups and individuals are always given a post-test to students (interview, 10 July 2020).

\subsection{Learning Evaluation}

Learning evaluation is an activity to assess what is carried out in the learning process which includes planning, implementation, and the assessment process as well as the impact on students. This evaluation is carried out to be able to correct deficiencies in learning and can be the basis for the next learning process (Lukum, 2015). Learning evaluation is an indicator tool in assessing the achievement of predetermined goals and evaluating the overall learning process. Evaluation is not just an incidental and spontaneous assessment of activities but an activity to assess something systematically, planned, and directed based on clear objectives (Hanum, 2013). As the results of learning the history of the national movement to foster diversity values, students see various aspects of assessment and evaluation of learning. The history teacher at National Senior High School has done it thoroughly well.

According to Anas (2007), learning evaluation can be carried out well if it is guided by three principles, namely the overall principle, the principle of sustainability, and the principle of objectivity. This means that a comprehensive and sustainable principle has been carried out well by history teachers because the aspects used to assess learning outcomes are based on cognitive, affective, and psychomotor aspects. The assessment aspects of the national movement history subject based on the assessment format document consist of 1. Attitude aspects such as self-assessment, peer assessment, and observation assessment. 2. Knowledge aspects such as observation or oral tests on discussions, 
making individual papers, and mind mapping as group assignments, assignments, conversations, and practice questions and answers in dialogue or monologue, post-tests, multiple-choice, description and writing. Project appraisal, performance appraisal, portfolio appraisal, and product appraisal.

Regarding the evaluation of learning history, the national movement of history teachers, in evaluating learning, said:

"Evaluation in the teaching of the history of the national teacher movement has used the principle of overall and continuous evaluation and has been carried out well by history teachers. This is based on the fact that the aspects used as an assessment of learning outcomes are guided by cognitive, affective, and psychomotor aspects" (interview 3 July 2020).

The results that can be learned from learning the history of the national movement to foster diverse values in students are changes in behavior. This is by the opinion of Schunk (2012). Three learning criteria are formulated (1) involving changes in behavior in learning. People are called learning if they can do something differently (2) learning and teaching last over time, so that temporary changes in behavior are not included in it. (3) through learning, experiences occur, whether through direct practice or observing the behavior of others.

\subsection{Barriers Faced in Learning}

The history teacher explains the values of diversity, it does not mean that students can directly respond to the explanation and foster positive reactions in the form of characterized behavior. It takes time for students to be able to cultivate the values of diversity in themselves, and it does not rule out that in learning the history of the national movement to foster students' diversity values there are several obstacles.

Regarding the obstacles faced in learning the history of the national history teacher movement, he said:

"The learning barrier is due to the current Covid-19 pandemic, so the learning process is carried out online so that students cannot socialize directly with students and see what students are doing at home as when learning is carried out in class. Only done by the students" (interview 3 July 2020).

Furthermore, the history teacher said:

"Students if given too much subject matter students can feel bored in learning, and because currently learning is done online via WhatsApp social media so that teachers cannot monitor and see what students are doing as it is when learning is done in class (interview 3 July 2020). 
The efforts made by the history teacher in overcoming the barriers to learning the history of the national movement to foster diversity values, namely the teacher making himself a role model for his students, and motivating students to always remember the services of the nation's heroes who fought together even though they were different. Both ethnicity, race, social system, and culture are still one in realizing Indonesia's independence (interview 3 July 2020).

\section{Conclusions}

The conclusion is, first, planning the history of the national movement. The history teacher has prepared and compiled the lesson plan and learned the syllabus following the rules of the 2013 curriculum. Second, the implementation of learning the history of the national movement. History teachers in teaching material on the history of the national movement use the group discussion method, training students to respect their friends who have different opinions such as differences in religion, ethnicity, race, social system, or culture that are different from one another, history teachers teach national movement figures to students and not just one figure, but several important figures during the national movement, so that in this way the students' diversity values can continue to develop and increase. Third, evaluation in the history learning of the national history teacher movement has used the principle of overall and continuity evaluation and has been carried out properly by history teachers. This is based on the fact that the aspects used as an assessment of learning outcomes are guided by cognitive, affective, and psychomotor aspects. Third, currently learning is carried out online via WhatsApp social media so that teachers cannot see what students are doing at home as is the case when learning is done in class. The efforts made by the history teacher in overcoming the barriers to learning the history of the national movement, namely the teacher making himself a role model for his students, and motivating students to always remember the services of the national heroes who fought together even though they were different in ethnicity, race, social system, and culture, but they are still one in realizing Indonesian independence. In the end, the obstacles to learning historical figures to foster diversity values were overcome, so that the diversity values of students increased.

\section{References}

Anas, S. (2007). Pengantar Evaluasi Pendidikan. Depok: PT. Grafindo Persada.

Anderson, B. (1983). Imagined Communities: Reflections on the Origin and Spread of Nationalism. London: Verso.

Appadurai, A. (1993). Modernity at large, Culture Dimensions of Globalization. London: University of Minnesota.

Collingwod, R. G. (1973). The Idea of History. Oxford: Oxford University Press.

Driyarkara, D. (1980). Driyarkara Tentang Pendidikan. Yogyakarta: Kanisius. 
Hanum, N. S. (2013). Keefetifan e-learning sebagai media pembelajaran (studi evaluasi model pembelajaran e-learning SMK Telkom Sandhy Putra Purwokerto). Jurnal Pendidikan Vokasi, 3(1), 90-102. https://doi.org/10.21831/jpv.v3i1.1584

Hazlitt, H. (2003). Dasar-Dasar Moralitas. Yogyakarta: Pustaka Pelajar.

Ilyasin, I., Amin, S., \& Atmaja, H. T. (2019). Persepsi Siswa Etnis Tionghoa Terhadap Pembelajaran Sejarah Pokok Bahasan Pergerakan Nasional di SMA Kristen Wonosobo. Indonesian Journal of History Education, 7(1), 67-78. https://doi.org/10.15294/ijhe.v7i1.30680

Indah, W. P. U., \& Nugroho Widiadi, A. (2016). Wacana Bhineka Tunggal Ika Dalam Buku Teks Sejarah. Paramita, 26(1), 106-117. https://doi.org/ISSN: 0854-0039

Ki Hadjar Dewantara. (1967). Ki Hadjar Dewantara Tentang Pendidikan, Taman Siswa, Yogyakarta.

Lukum, A. (2015). Evaluasi Program Pembelajaran IPA SMP Menggunakan Model Countenance Stake. Jurnal Penelitian Dan Evaluasi Pendidikan. https://doi.org/10.21831/pep.v19i1.4552

Muawanah. (2018). Pentingnya Pendidikan Untuk Tanamkan Sikap Toleran Di Masyarakat. Jurnal Vijjacariya, 5(1), 57-70.

Muhaemin, E., \& Sanusi, I. (2019). Intoleransi Keagamaan dalam Framing Surat Kabar Kompas. Communicatus: Jurnal Ilmu Komunikasi, 3(1), 17-34. https://doi.org/10.15575/cjik.v3i1.5034\%0A

Muslim, Warto, \& Djono. (2020a). Implementing Student Tolerance and Patriotism Through Learning History of National Movements. International Journal of Social Science and Religion (IJSSR), 1(3), 281-294. https://doi.org/https://doi.org/10.2020/ijssr.v1i3.28

Muslim, M., Warto, W., \& Djono, D. (2020). Menumbuhkan Nilai Toleransi dan Patriotisme Siswa Melalui Pembelajaran Tokoh Sejarah Pergerakan Nasional. The Journalish: Books Collection, 1(7), 1-191.

Muslim, W., \& Djono, D. (2020c). Implementing Tolerance Values and Patriotsm Through History Learning at SMA Negeri 11 Yogyakarta. Seminar Nasional Pembelajaran Sejarah (SNPS UNS 2020), 60-68. https://doi.org/https://doi.org/10.20961/shes.v3i2.46222

Nugroho, A., \& Putri W. M. (2016). Peran Pendidikan Karakter Dalam Menanamkan Nilai-Nilai Kebhinnekaan. Prosiding Seminas Nasional Psikologi Indigenous Indonesia 2016 "Kebhinekaan Dan Masa Depan Indonesia: Peran Ilmu Sosial Dalam Masyarakat" Universitas Negeri Malang - 27 Agustus 2016, 398-411.

Pambud, S., Utomo, S. T., \& Muanayah, N. A. (2020). Arts Based Education Relevance in SeratWedhatama By K.G.P.A.A Mangkunegaran IV in Nusantara. International Journal of Social Learning, 1(1), 42-53. https://doi.org/https://doi.org/10.47134/ijsl.v1i1.6.

Pi'i. (2017). Penanaman Nilai-Nilai Kebhinekaan Melalui Pembelajaran Sejarah SMA. Sejarah dan Budaya: Jurnal Sejarah, Budaya, Serta Pengajarannya, 11(2), 180-191.

Pujiono, P., Fidiyani, R., Sugiarto, L., \& Prabowo, M. S. (2019). Penanaman Nilai Bertoleransi dalam Kehidupan Kebebasan Beragama Bagi Siswa Sekolah Menengah Kejuruan (SMK). Jurnal Pengabdian Hukum Indonesia (Indonesian Journal of Legal Community Engagement) JPHI, 1(2), 101-122. 
Rohmat, M. (2004). Mengartikulasikan Pendidikan Nilai. Bandung: Alfabeta.

Rowse, A. L. (1963). The Use of History. New York: Macmillan \& Co.

Reni, D., \& Sudrajat, A. (2017). Golongan Tua Menggagas Pergerakan Nasional: Pemikiran R.M.T Koesoemo Oetoyo di Bidang PolitikTahun 1908-1942. Agastya: Jurnal Sejarah Dan Pembelajarannya. https://doi.org/10.25273/ajsp.v7i2.1487

Sahal, M., Musadad, A. A., \& Akhyar, M. (2018). Tolerance in Multicultural Education: A Theoretical Concept. International Journal of Multicultural and Multireligious Understanding (IJMMU), 5(4), 115-122. DOI: http://dx.doi.org/10.18415/ijmmu.v5i4.212

Schunk, D. H. (2012). Teori-Teori Pembelajaran Persfektif Pendidikan (keenam). Yogyakarta: Pustaka Pelajar.

Supardan, D. (2005) History Learning on The Approach Of Multicultural and Local, National, Global History Perspective For National Integration : A Quasi-Experimental Study on Senior High School Student in Bandung City, Thesis, Universitas Pendidikan Indonesia.

Rambe, T. (2017). Membingkai Kebhinekaan dan Kedaulatan dalam Berbangsa dan Bernegara dari Sudut Pandang Sosial Politik Nasional. Jurnal Generasi Kampus, 10 (2), 211-233.

Setianto, Y. (2019). Pendidikan Karakter Melalui Keteladanan Pahlawan Nasional. Jurnal Publikasi Pendidikan, 9, 181-182.

Sudarsih, S. (2019). Pentingnya Penanaman Nilai-Nilai Budaya Lokal dalam Keluarga di Era Global. Endogami: Jurnal Ilmiah Kajian Antropologi, 3(1), 68-70.

Thoha, M. C. (1996). Kapita Selekta Pendidikan Islam. Yogyakarta: Pustaka Pelajar.

Utami, I. W. P., \& Widiadi, A. N. (2016). Wacana Bhineka Tunggal Ika dalam Buku Teks Sejarah. Paramita, 26(1), 106-117.

Trisnowaty, T. (2009). Hubungan Antara Pemahaman Sejarah Pergerakan Nasional Indonesia dengan Sikap Terhadap Bela Negara. Jurnal Kependidikan, 39(1), 1-10.

Vanderburg, W. (1985). Minds and Cultures. New York: Little Brown and Company Limited.

Yin, R. K. (2003). Studi Kasus: Desain \& metode. (Terj. M. DJauzi Mudjakir (ed.)). PT. Raja Grafindo persada.

Zais, R. S. (1976). Curriculum: Principles and Foundations. New York: Harper \& Row Publisher. 